\title{
Retrospective Evaluation of Patients Diagnosed with Cystic Echinococcosis at Kafkas University Faculty of Medicine’s Surgical Outpatients Unit
}

\author{
Kafkas Üniversitesi Tıp Fakültesi Cerrahi Polikliniklerine Başvuran Kistik Ekinokokkozis Tanılı \\ Hastaların Retrospektif Olarak Değerlendirilmesi
}

\section{Neriman Mor $^{1}$ (D), Tülay Diken Allahverdi² (B), Ertuğrul Allahverdi ${ }^{3}$ (D) Ümit Yener Tekdoğan ${ }^{4}$ (D)}

1Department of Parasitology, Kafkas University School of Medicine, Kars, Turkey

2Department of Surgery, Kafkas University School of Medicine, Kars, Turkey

${ }^{3}$ Department of Orthopedics, Kafkas University School of Medicine, Kars, Turkey

${ }^{4}$ Department of Urology, Kafkas University School of Medicine, Kars, Turkey

Cite this article as: Mor N, Diken Allahverdi T, Allahverdi E, Tekdoğan ÜY. Retrospective Evaluation of Patients Diagnosed with Cystic Echinococcosis at Kafkas University Faculty of Medicine's Surgical Outpatients Unit. Turkiye Parazitol Derg 2018; 42(3): 196-201.

\section{ABSTRACT}

Objective: The aim of this study was to retrospectively evaluate the serological and radiological analysis and medical and surgical treatment results of patients diagnosed with cystic echinococcosis (CE).

Methods: Records belonging to a total of 67 patients diagnosed with CE who presented to the Kars Kafkas University Faculty of Medicine Research Hospital's Surgical Outpatient unit between January 2012 and December 2015 were retrospectively evaluated.

Results: Of 67 CE cases, 53 (79.1\%) were females and 14 (20.9\%) were males. The age ranged between 12 and 77 years, and the mean age was $47.37 \pm 17.81$ years. The most common cyst location was the liver, in 60 patients (89.5\%). Other localizations were found in 7 (10.5\%) of the 67 cases. Open surgery was used to treat 32, and drainage accompanied by ultrasonography (USG) was used to treat 13 cystic cases. The remaining 22 patients were followed-up. Among the followed-up patients, the radiologic imaging findings of six patients were consistent with a hydatid cyst, but the indirect hemagglutination assay (IHA) results were negative.

Conclusion: We concluded that $\mathrm{CE}$ is an important public health problem for the Kars region due to a low socioeconomic and educational level, where livestock breeding is also common. More comprehensive epidemiological studies should be undertaken and national control programs are required to keep the disease under control.

Keywords: Cystic echinococcosis, surgical treatment, percutaneous drainage, Kars, Turkey

$\begin{array}{lll}\text { Received: 25.11.2016 Accepted: } 10.04 .2018 & \text { Available Online Date: } 18.04 .2018\end{array}$

\section{Öz}

Amaç: Bu çalışma ile kistik ekinokokkozis tanılı olgularımızın serolojik ve radyolojik tanı, medikal ve cerrahi tedavi sonuçlarının retrospektif olarak değerlendirilmesi amaçlanmıştır.

Yöntemler: Ocak 2012 ile Aralık 2015 yılları arasında Kars Kafkas Üniversitesi Tıp Fakültesi Araştırma Hastanesi cerrahi polikliniklerine başvuran toplam 67 tanı almış KE'li hastalara ait kayıtlar geriye dönük olarak incelenmiştir.

Bulgular: Elde edilen sonuçlara göre toplam $67 \mathrm{KE}$ olgusunun 53'ü $(\% 79,1)$ kadın, 14'ü $(\% 20,9)$ erkek hastalardan oluşmuştur. Yaşları 12 ile 77 arasında

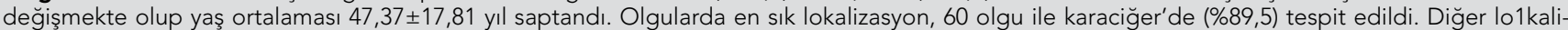
zasyonlar 67 olgunun 7'sini $(\% 10,5)$ oluşturmaktaydı. Kistik olgulardan 32'si açık cerrahi yolla, 13'ü ise USG eşliğinde drenaj uygulanarak tedavi edildi. Kalan 22 hasta ise takip edildi. Takip edilen hastalardan 6 olgunun radyolojik görüntüleme tetkiklerinde kist hidatikle uyumlu olduğu fakat Indirect Haemaglutination assay (IHA) sonucunun negatif olduğu tespit edildi.

Sonuç: Hayvancılı̆̆ın yaygın olarak yapıldığı bölgemizde sosyo-ekonomik düzeyin düşüklüğü ve halkın eğitim eksikliği gibi nedenlerle KE'in Kars bölgesi için önemli bir halk sağlığı problemi olduğu, hastalığın kontrol altına alınması için daha geniş çaplı epidemiyolojik araştırmaların yapılması gerektiği ve ulusal kontrol programlarına ihtiyaç duyulduğu kanısına varılmıştır.

Anahtar Kelimeler: Kistik ekinokokkozis, cerrahi tedavi, perkütan drenaj, Kars, Türkiye

Geliş Tarihi: 25.11.2016

Kabul Tarihi: 10.04 .2018

Çevrimiçi Yayın Tarihi: 18.04.2018

Address for Correspondence / Yazışma Adresi: Neriman Mor E.mail: nery.man@hotmail.com DOI: $10.5152 /$ tpd.2018.5137

(C) Copyright 2018 Turkish Society for Parasitology - Available online at www.turkiyeparazitolderg.org

(O)Telif hakkı 2018 Türkiye Parazitoloji Derneği - Makale metnine www.turkiyeparazitolderg.org web sayfasından ulaşılabilir. 


\section{INTRODUCTION}

Cystic echinococcosis (CE) is a global illness caused by Echinococcus granulosus (E. granulosus). It is mostly seen in regions where stockbreeding is common, and it results in significant health problems and financial loss (1).

E. granulosus hydatid cysts are most commonly found in the liver (44\%-65\%), followed by the lungs (25\%-31\%), and less commonly the brain, heart, bone, kidney, and spleen $(10 \%-25 \%)(2,3)$. It is endemic in South America and the Far East, Middle East, and Mediterranean regions, especially in countries with poor socioeconomic development where sheep breeding is common (4). Although the prevalence of the disease in Turkey varies by region, it is most common in Eastern Anatolia, Southeastern Anatolia, and Central Anatolia $(5,6)$. It is also rarely encountered in the western regions that attract migration from the eastern regions (7). There have been two previous studies conducted on humans with $\mathrm{CE}$ in the Kars province. A serological prevalence of $34.6 \%$ was reported in the study by Karaman et al. (8), and females have been reported to suffer from the disease more frequently (9).

The careful removal of cyst content without spreading it is an ideal surgical treatment method in terms of preventing the hydatid cyst recurrence. Systemic chemotherapy (albendazole), surgical procedures, or radiologically performed percutaneous drainage methods are currently used in the treatment $(10,11)$.

The aim of our study was to retrospectively evaluate the medical, surgical, radiologic, and treatment results of the cases diagnosed with CE at Kafkas University Medical Faculty Surgical Outpatients. In this study, we aimed to retrospectively evaluate the serological and radiological analysis and medical and surgical treatment results of the cases that presented to Kafkas University Medical Faculty surgery outpatients and were diagnosed with CE.

\section{METHODS}

The records of 67 patients, i.e., 52 females and 14 males aged 12 to 77 years, diagnosed with CE and followed-up at the Kars Kafkas University Faculty of Medicine's Department of Surgery between January 2012 and December 2015, were evaluated retrospectively. This study was approved by the Faculty of Medicine's Ethics Committee Chair of Kafkas University (Kafkas University local Ethics Committee-80576354-050- 99/22), and other necessary permissions from the Rectorate were obtained before the study. Descriptive statistics were used to compare findings such as age, gender, the treatment method, serological results, cyst location, the number of cysts according to the radiological diagnosis, and cyst type according to the Gharbi classification from the patient charts, and the results were expressed as numerals and percentages. Albendazole (Andazol ${ }^{\circledR} 15 \mathrm{mg} / \mathrm{kg}$, tablet, Biofarma, Istanbul, Turkey) treatment at a dose of $15 \mathrm{mg} /$ $\mathrm{kg} /$ day was administered for 6 months to prevent recurrence after surgical treatment or percutaneous drainage. Liver functions were checked monthly during treatment. Type-4 and Type5 calcified cysts were followed-up with imaging methods at the 6-month intervals. Imaging was used to check if there were any increases in the cyst diameter, daughter vesicles in calcified cysts, and new cysts that had developed elsewhere. The cysts were seen to remain inactive during the follow-up period from the chart information. Therefore, no intervention was required.

The results of 811 patients suspected of having CE and investigated by the commercial indirect haemagglutination assay (IHA) (Hydatidose, Fumouze Laboratoires, France) method serologically between 2012 and 2015 were evaluated. The values of $1 / 160$ and above at serum dilutions were accepted as positive in the analysis conducted by the IHA method.

\section{Statistical Analysis}

For the statistical analysis, the IBM Statistical Package for the Social Sciences Statistics 20.0 (IBM SPSS Statistics; Armonk, NY, USA) software was used. The mean and standard deviation and minimum-maximum values were compared between the age groups. The differences between the genders were statistically evaluated using the Mann-Whitney $U$ test. $P<0.05$ was accepted as statistically significant.

\section{RESULTS}

The distribution of the CE cases by gender and age groups is presented in Table 1. There were $20.9 \%$ males and $79.1 \%$ females. A statistically significant difference was found between the genders $(p<0.05)$. The youngest patient was 12 and the oldest 77 years old, with the mean age of $47.37 \pm 17.81$ years. The most common age range was $40-59$ years at a rate of $35.8 \%$, followed by $20-39$ years at $29.9 \%, 60$ years and above at $25.4 \%$, and $0-19$ years at $8.9 \%$. Open surgery was performed in 32 and drainage accompanied by USG in 13 cystic cases. The remaining 22 patients were found to be suitable for follow-up. The most common cyst location was the liver with 60 cases (89.5\%). It was followed by the kidney (1.5\%), spleen (1.5\%), pancreas (1.5\%), and the abdomen (1.5\%). Multi-organ involvement (liver+lung, liver+gallbladder, and liver+bone pelvis was observed in three cases (Figure 1). The cyst was thought to be primary in 64 (95.5\%)

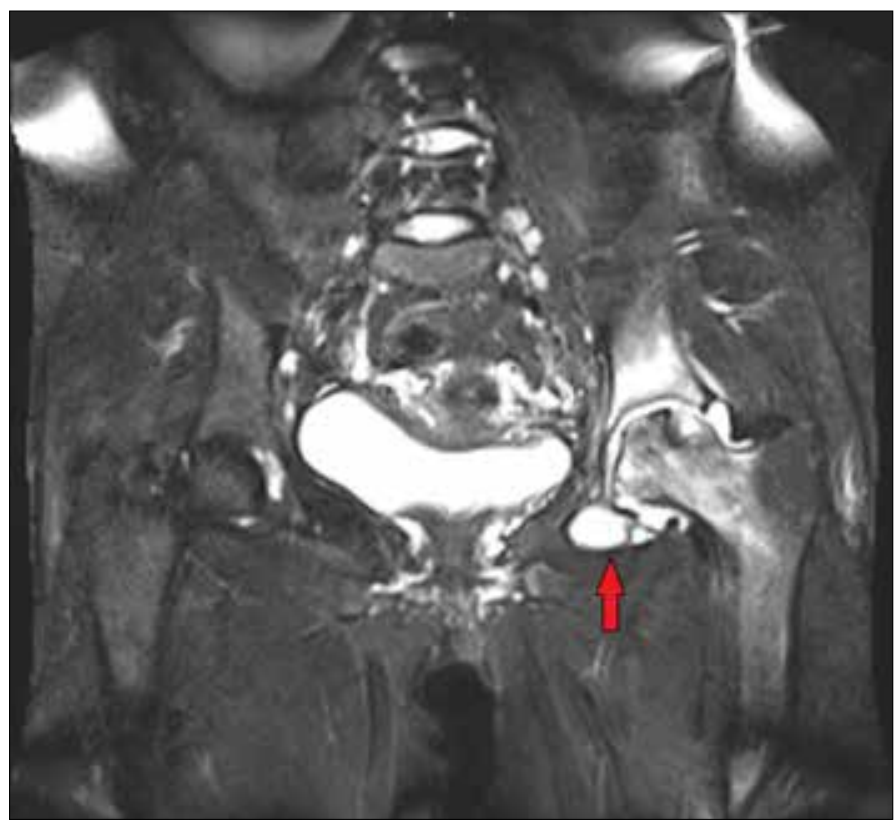

Figure 1. T2-sequence magnetic resonance image of the hydatid cyst involvement in the left hip joint 
Table 1. Gender, age, treatment form, and distribution of the cyst by location in patients with cystic echinococcosis

\begin{tabular}{|c|c|c|}
\hline & $\begin{array}{c}\text { Total } \\
\mathbf{n}\end{array}$ & $\%$ \\
\hline \multicolumn{3}{|l|}{ Gender } \\
\hline Female & 53 & 79.1 \\
\hline Male & 14 & 20.9 \\
\hline \multicolumn{3}{|l|}{ Age group } \\
\hline $0-19$ & 6 & 8.9 \\
\hline $20-39$ & 20 & 29.9 \\
\hline $40-59$ & 24 & 35.8 \\
\hline 60 and above & 17 & 25.4 \\
\hline \multicolumn{3}{|l|}{ Treatment form } \\
\hline Surgery & 32 & 47.8 \\
\hline $\begin{array}{l}\text { Drainage accompanied by } \\
\text { ultrasonography }\end{array}$ & 13 & 19.4 \\
\hline Follow-up & 22 & 32.8 \\
\hline \multicolumn{3}{|l|}{ Site of the cyst } \\
\hline Liver & 60 & 89.5 \\
\hline Liver+lung & 1 & 1.5 \\
\hline Liver+gallbladder & 1 & 1.5 \\
\hline Liver+pelvic bone & 1 & 1.5 \\
\hline Kidney & 1 & 1.5 \\
\hline Spleen & 1 & 1.5 \\
\hline Pancreas & 1 & 1.5 \\
\hline Abdomen & 1 & 1.5 \\
\hline \multicolumn{3}{|l|}{ Surgical procedures used } \\
\hline Partial cystectomy+external drainage & 3 & 9.4 \\
\hline Partial cystectomy+omentoplasty & 22 & 68.7 \\
\hline Liver left lateral segmentectomy & 2 & 6.3 \\
\hline $\begin{array}{l}\text { Liver right segmentectomy } \\
\text { (segment V)+cholecystectomy }\end{array}$ & 1 & 3.1 \\
\hline Total cystectomy & 2 & 6,3 \\
\hline Total splenectomy & 1 & 3.1 \\
\hline Subtotal pancreatectomy & 1 & 3.1 \\
\hline
\end{tabular}

and secondary in 3 (4.5\%) cases. The most common surgical intervention was partial cystectomy+omentoplasty at a rate of $68.7 \%$, followed by partial cystectomy+external drainage at a rate of $9.4 \%$, liver left lateral segmentectomy and total cystectomy at a rate of 6.3\%, and liver right segmentectomy (Segment V)+cholecystectomy, total splenectomy, and subtotal pancreatectomy at a rate of $3.1 \%$.

Liver cyst hydatid cases were most commonly found in the right lobe and Segments VI, VII, and VIII (Table 2). The hydatid cyst types were Type-3, Type-5, Type-2, Type-4, and Type-1, respectively, according to the Gharbi classification (Table 3).

General Surgery outpatients was the source of 382 of the 811 serums investigated, and 153 (40.0\%) gave a reactive result at
Table 2. The liver segment and the number of cysts in patients with a liver hydatid cyst

\begin{tabular}{|l|c|}
\hline Liver Segment & $\mathbf{n}$ \\
\hline I & 1 \\
\hline II & 9 \\
\hline III & 7 \\
\hline IV & 7 \\
\hline V & 8 \\
\hline VI & 15 \\
\hline VII & 18 \\
\hline VIII & 19 \\
\hline Total & 84 \\
\hline
\end{tabular}

Table 3. Gharbi classification

\begin{tabular}{|l|c|}
\hline Gharbi Classification & $\mathbf{n}(\%)$ \\
\hline Type 1 & $6(9.0)$ \\
\hline Type 2 & $13(19.4)$ \\
\hline Type 3 & $21(31.3)$ \\
\hline Type 4 & $11(16.4)$ \\
\hline Type 5 & $16(23.9)$ \\
\hline
\end{tabular}

Table 4. The distribution of Indirect Hemagglutination Assay (IHA) test results by titer

\begin{tabular}{|l|c|c|}
\hline Titer & Number of Positive Samples & $\%$ \\
\hline $1 / 160$ & 15 & 22.4 \\
\hline $1 / 320$ & 14 & 20.9 \\
\hline $1 / 640$ & 24 & 35.8 \\
\hline $1 / 1280$ & 3 & 4.5 \\
\hline $1 / 2560$ & 5 & 7.5 \\
\hline Negative & 6 & 8.9 \\
\hline Total & 67 & 100 \\
\hline
\end{tabular}

various titers. In conclusion, 67 of the 153 patients with positive reaction results accepted the treatment. Open surgery and drainage accompanied by USG were implemented in only 45 patients. The IHA test result was negative in six of the 22 patients that were followed-up. However, these patients were accepted as the hydatic cyst cases according to the radiologic imaging analysis and were followed-up accordingly. The distribution of the IHA test results of these cases by titer is shown in Table 4. The cases were accepted as CE from the pathology specimens obtained during surgery or the interventions performed accompanied by percutaneous USG (Figure 2a, b).

No recurrence was observed during the 3 years of follow-up in any of the patients treated with open surgery or the percutaneous drainage method. No cyst activation or new cyst formation was observed in the 22 patients who were followed-up only by drug treatment (albendazole). 

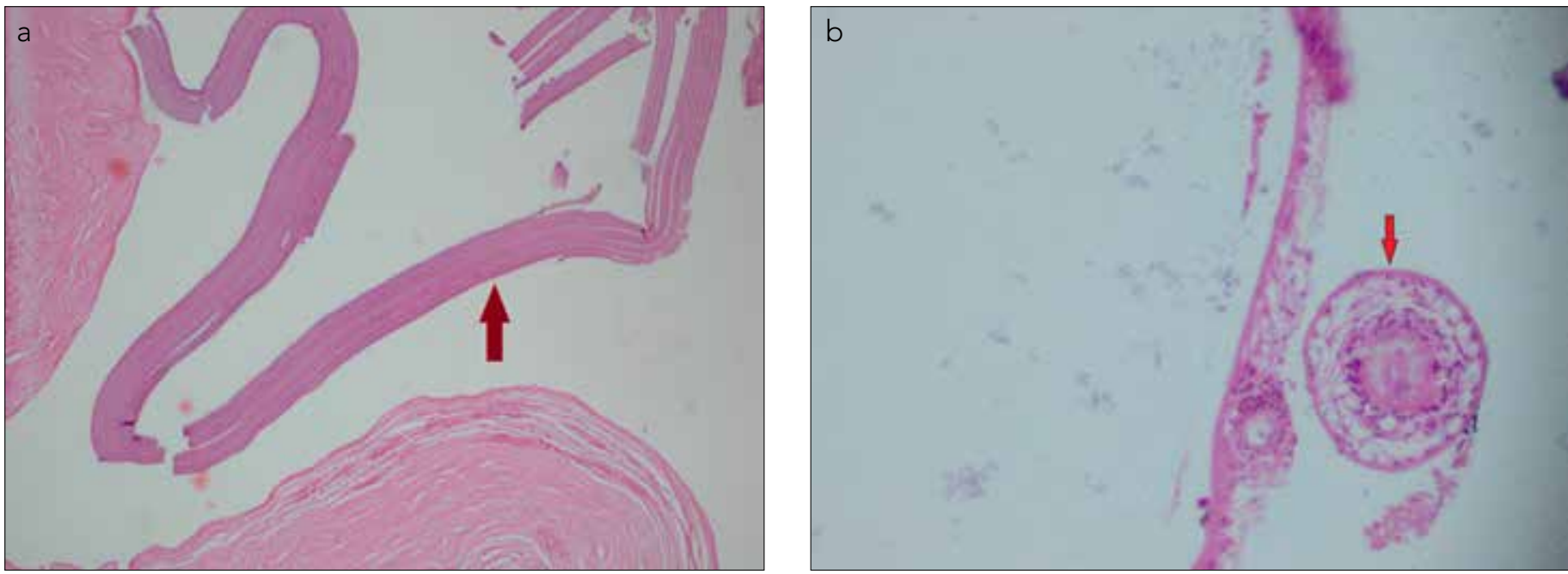

Figure 2. a, b. (a) Homogeneous, lamellar, avascular, and acellular cuticle layer (H-Ex100). (b) Scolexes observed in the second cyst lumen $(\mathrm{H}-\mathrm{Ex} 400)$

\section{DISCUSSION}

Cystic echinococcosis is a zoonotic parasitic disease that has been recognized for many years and continues to be a current and important issue for human and animal health among the helminthic diseases due to the economic losses it causes in our country and worldwide. Although the disease has been eradicated in certain developed countries, it still remains problematic in underdeveloped and developing countries due to factors such as cattle and sheep breeding without possessing the necessary knowledge, uncontrolled and indiscriminate slaughter, feeding the organs of infected animals to dogs, contact with infected dogs, and the presence of stray dogs $(1,6)$.

Various results have been reported regarding the gender distribution of $C E$. The CE rate in females and males in various countries varies according to the relationship of people with the environment they live in and their close contact with dogs. Females were observed to experience the disorder more frequently in the previous studies from Turkey (12-14). Various hospital records and Province Health Directorate records between 1999 and 2004 were investigated in terms of hydatid cyst in a study, and the results revealed 330 (47.2\%) male and 369 (52.8\%) female patients for a total of 699 hydatid cyst cases (15). Kaplan et al. (16) reported that $54.8 \%$ of the cases were female and $45.2 \%$ male in their study. A similar study of ours from the Kars province of Turkey included 168 cases consisting of 101 (60.1\%) females and 67 (39.9\%) males (9). Females also made up 79.1\% of the cases in this study. Our cases were mostly from rural areas. One of the possible reasons could be that women are involved in animal care, cultivating, and cooking and cleaning, while the men deal with agriculture and land affairs.

The disease has been reported in all ages, and infection that starts in childhood commonly gives rise to symptoms between the ages of 20 and 50 years in the studies on cystic echinococcosis conducted in Turkey (12). Delibaş et al. (13) reported that $46 \%$ of the cases aged from 40 to 60 years. Our youngest patient was 12 and the oldest 77 years old. There were 61 cases aged 20 years, and most patients (35.8\%) were in the age group between
40 and 59 years. The distribution of these cases by age was parallel to other studies, most being young adults.

Surgical intervention preserves its place as the first option in CE treatment. Although the location and number of cysts determine the treatment method to be used, the method selected affects the hospitalization duration and rate of complications (17-19). The aim of the surgical treatment is to kill the daughter vesicles with protoscolocidal agents and to remove the cyst content together with the germinal membrane in a controlled manner and without spreading it to surrounding tissues $(10,20,21)$. Open and/or laparoscopic methods can be used for surgical treatment. Laparoscopic surgery can be performed for cysts in the early stage that develop away from the liver and that are calcified and uncomplicated. The number of cysts, their location, and the experience of the surgeon also play a role in the success of surgery (11). Partial cystectomy, capitonnage, marsupialization, unroofing, introflexion, partial liver resection or lobectomy together with cyst resection, and pericystectomy can be performed during open surgery. The objectives of closing the cyst cavity with omentum are to absorb the dead space and fluid content and decrease the risk of infection $(10,21)$.

Surgery was performed in $47.8 \%$ of our cases, and drainage accompanied by USG in $19.4 \%$. Partial cystectomy+omentoplasty was the most commonly used surgical procedure at a rate of $68.7 \%$, and no laparoscopic surgical intervention was performed. The reason was the lack of surgeon experience with this technique at our hospital and our patients preferring percutaneous drainage in the early stages. The hospitalization duration varied according to the treatment method, and no complications were seen. This duration is 1 day for patients treated with the drainage method accompanied by USG and 10 to 21 days for patients who have undergone surgery (17-19). The mean hospitalization durations in our study were similar to other reports at 3 to 35 days.

The recurrence rate after surgical treatment is reported to be between $2 \%$ and $25 \%$ in the literature (20-22). Some studies report a lower recurrence rate in cases treated with albendazole (23-25). No recurrence was observed in 3 years of follow-up in 
our patients who had undergone open surgery or percutaneous drainage. We therefore believe that the percutaneous drainage method accompanied by USG is effective in properly selected patients, in addition to the surgical treatments previously reported in the literature $(10,26,27)$.

The Gharbi classification is used for liver lesion typing when deciding on percutaneous treatment $(28,29)$. Type-1, Type-2, Type-3, and fluid-containing Type-4 cysts were accepted as active in this classification and treated. Type- 1 and Type- 2 cysts were treated with the percutaneous drainage method in this study. Percutaneous drainage was not thought to be suitable for Type- 3 cysts as they contain daughter vesicles and for Type-4 cysts as they contain daughter vesicles and sometimes calcification. No recurrence was seen at the post-treatment follow-up of the patients that had undergone percutaneous drainage. The 22 (32.8\%) patients with Type-4 and Type-5 cysts were monitored for 6 months. The cysts were thought to be inactive due to the calcification they contained.

Cystic echinococcosis is usually an infection that remains hidden throughout the life of the patient. It is mostly seen in the right liver lobe. A total of 84 cysts were found in the 67 patients we included in the study, and 60 (71.4\%) of these cysts were located in the right liver lobe. The reason may be that the right liver lobe is commonly larger and has a better portal blood supply $(1,30)$.

Several known serologic tests can be used in the diagnosis and follow-up but IHA and the enzyme-linked immunosorbent assay (ELISA) tests are preferred, and verification tests such as the western blot and molecular tests are quickly becoming established in the diagnosis (13). The sensitivity and specificity of the serologic tests in use are related to the structure, size, localization, and vitality of the cyst, immune status of the person, type of antigen used, preparation form of the antigen, and the method used (31). The IHA method is often preferred for CE diagnosis due to reasons such as obtaining the results in a short time, not requiring expensive laboratory tools, and easy implementation (32). The IHA method has been used by many investigators for CE diagnosis, and positive results between $52 \%$ and $93 \%$ have been reported (33). The IHA method revealed seropositivity in $196(24.2 \%)$ of the 811 patients who came from all clinics in our study. Seropositivity was found in 153 (40.0\%) of 382 patients who presented to the General Surgery outpatient. Only 67 of these patients with confirmed clinical and radiological findings accepted treatment, and others either went to treatment centers in big provinces or rejected treatment. The highest positivity was a titer of $1 / 640$ seen at a rate of $35.8 \%$ among the 67 cases tested with the IHA method. Yılmaz et al. (34) found a $34.6 \%$ seropositivity rate with the IHA method and reported the highest positivity as a titer of $1 / 640$ in a serologic study they conducted in the neighboring province of Erzurum.

\section{CONCLUSION}

We saw that the hydatic cyst was an important health problem due to a high (40.0\%) sero-positivity rate and that CE was widespread because of reasons such as the low socioeconomic and educational level of the region. Surgical treatment as well as percutaneous treatment should be the preferred treatment methods for this disease. We believe this will decrease the treatment cost and make an important contribution to our country's economy. Emphasizing public health trainings, taking precautions for dogs without owners, inspecting slaughterhouses regularly, and destruction of the organs that may contain cysts will be effective in fighting against the disease. More extensive studies on the subject are required.

Ethics Committee Approval: Ethics committee approval was received for this study from the ethics committee of Kafkas University School of Medicine (Ethics Committee-80576354-050-99/22).

Informed Consent: Informed consent was not received due to the retrospective nature of the study.

Peer-review: Externally peer-reviewed.

Author Contributions: Concept - N.M.; Design - N.M., T.D.A.; Supervision - Ü.Y.T.; Funding - N.M.; Materials - N.M., T.D.A., E.A., Ü.Y.T.; Data Collection and/or Processing - N.M., T.D.A., E.A., Ü.Y.T.; Analysis and/or Interpretation - N.M., T.D.A.; Literature Review - N.M.; Writing N.M.; Critical Review - N.M., T.D.A., E.A., Ü.Y.T.

Conflict of Interest: No conflict of interest was declared by the authors.

Financial Disclosure: The authors declared that this study has received no financial support.

Etik Komite Onayı: Bu çalışma için etik komite onayı Kafkas Üniversitesi Tıp Fakültesi'nden (80576354-050- 99/22) alınmıştır.

Hasta Onamı: Çalışmanın retrospektif tasarımından dolayı hasta onamı alınmamıştır.

\section{Hakem Değerlendirmesi: Dış bağımsız.}

Yazar Katkıları: Fikir - N.M.; Tasarım - N.M., T.D.A.; Denetleme - Ü.Y.T.; Kaynaklar - N.M.; Malzemeler - N.M., T.D.A., E.A., Ü.Y.T.; Veri Toplanması ve/veya İşlemesi - N.M., T.D.A., E.A., Ü.Y.T.; Analiz ve/veya Yorum - N.M., T.D.A.; Literatür Taraması - N.M.; Yazıyı Yazan - N.M.; Eleştirel Inceleme - N.M., T.D.A., E.A., Ü.Y.T.

Çıkar Çatışması: Yazarlar çıkar çatışması bildirmemişlerdir.

Finansal Destek: Yazarlar bu çalışma için finansal destek almadıklarını beyan etmişlerdir.

\section{REFERENCES}

1. Özbilgin A, Kilimcioğlu AA. Cystic Echinococcosis. In: Özcel, M.A, (Ed.), Özcel's Medical Parasite Diseases. Turkey Parasitology Association Publication No:22, Meta Basım, İzmir, 2007; 541-66.

2. Altıntaş N. Cystic and alveolar echinococcosis in Turkey. Ann Trop Med Parasitol 1998; 92: 637-42. [CrossRef]

3. Ozekinci S, Bakir S, Mizrak B. Evaluation of cystic echinococcosis cases given a histopathologic diagnosis from 2002 to 2007 in Diyarbakir. Turkiye Parazitol Derg 2009; 33: 232-5.

4. Athanassiadi K, Kalavrouziotis G, Loutsidis A, Bellenis I, Exarchos N Surgical treatment of echinococcosis by a transthoracic approach: a review of 85 cases. Eur J Cardiothorac Surg 1998; 14: 134-140. [CrossRef]

5. Altıntaş N, Yazar S, Yolasığmaz A, Akısü Ç, Şakru N, Karacasu F, et al. A serum epidemiological study of cystic echinococcosis in Izmir and its surrounding area, Turkey Helminthologia 1999; 36: 19-23.

6. Unat EK, Yücel A, Altaş K, Samastı M. Unat's Medical Parasitology, istanbul University Cerrahpaşa Faculty of Medicine Foundation Publications, Publication No: 15, İstanbul, 1995. 
7. Canda MŞ, Güray M, Canda T, Astarcioğlu H. The Pathology of echinococcosis and the current echinococcosis problem in western Turkey (A Report of Pathologic Features in 80 cases). Turk J Med Sci 2003; 33: 369-74.

8. Karaman Ü, Miman Ö, Kara M, Gıcık Y, Aycan ÖM, Atambay M. Hydatid cyst prevalence in the Kars region. Turkiye Parazitol Derg 2005; 29: 238-40.

9. Mor N, Allahverdi Diken T, Anuk T. The Situation of cystic echinococcosis in Kars state hospital for the last five years. Turkiye Parazitol Derg 2015; 39: 108-11. [CrossRef]

10. Sayek I, Tırnaksız MB, Doğan R. Cystic Hydatid Disease: Current trends in diagnosis and management. Surg Today 2004; 34: 987-96. [CrossRef]

11. Acarlı K. Controversies in the laparoscopic treatment of hepatic hydatid disease. HPB 2004; 6: 213-21. [CrossRef]

12. Ertuğ S, Sarı C, Gürel M, Boylu Ş, Çanakkalelioğlu L, Şahin B. Aydın ve çevresinde 1996-2000 yılları arasında cerrahi olarak saptanan kist hidatik olguları. Turkiye Parazitol Derg 2002; 26: 254-6.

13. Delibaş BS, Özkoç S, Şahin S, Aksoy Ü, Akısü Ç. Evaluation of patients presenting with a suspicion of cystic echinococcosis to the serology laboratory of the parasitology department of Dokuz Eylül University Medical Faculty. Turkiye Parazitol Derg 2006; 30: 279-81.

14. Hakverdi S, Çulha G, Canda MŞ, Yaldız M, Altıntaş S. Problem of cystic echinococcoss in Hatay. Turkiye Parazitol Derg 2008; 32: 340-2.

15. Yazar S. Cystic Echinococcosis in Kayseri during the last six years. Turkiye Parazitol Derg 2005; 29: 241-3.

16. Kaplan M, Aygen E, Özyurtkan MO, Bakal Ü. Cystic echinococcosis cases in Firat University Hospital Between 2005 and 2007. F.Ü. Sağ Bil Tıp Derg 2010; 24: 109-13.

17. Yagci G, Ustunsoz B, Kaymakcioglu N, Bozlar U, Gorgulu S, Simsek $A$, et al. Results of surgical, laparoscopic, and percutaneous treatment for hydatid disease of the liver: 10 years experience with 355 patients. World J Surg 2005; 29: 1670-9. [CrossRef]

18. Gourgiotis S, Stratopoulos C, Moustafellos P, Dimopoulos N, Papaxoinis $G$, Vougas $V$, et al. Surgical techniques and treatment for hepatic hydatid cysts. Surg Today 2007; 37: 389-95. [CrossRef]

19. Aygün E, Sahin M, Ödev K, Vatansev C, Aksoy F, Paksoy Y, et al. The management of liver hydatid cysts by percutaneous drainage. Can $J$ Surg 2001; 44: 203-9.

20. Jabbour N, Shirazi SK, Genyk Y, Mateo R, Pak E, Cosenza DC, et. al. Surgical management of complicated hydatid disease of the liver. Am Surg 2002; 68: 984-8.
21. McManus DP, Zhang W, Li J, Bartley PB. Echinococcosis. Lancet 2003; 362: 1295-304. [CrossRef]

22. Yorganci K, Sayek i. Surgical treatment of hydatid cysts of the liver in the era of percutaneous treatment. Am J Surg 2002; 184: 63-9. [CrossRef]

23. Morris DL. Albendazole treatment of hydatid disease; follow-up at 5 years. Trop Doct 1989; 19: 179-80. [CrossRef]

24. Chai J, Menghebat, Wei J, Deyu S, Bin L, Jincao S, et al. Observations on clinical efficacy of albendazole emulsion in 264 cases of hepatic cystic echinococcosis. Parasitol Int 2004; 53: 3-10. [CrossRef]

25. Liu $Y$, Wang $X$, Wu J. Continuous long-term albendazole therapy in intraabdominal cystic echinococcosis. Chin Med J (Engl) 2000; 113: 827-32.

26. Mcfall B, Yousaf M, Calvert H, Diamond T, Epanomeritakis M. Surgical treatment of hepatic hydatid cyst. Int J Clin Pract 2004; 58: 47982. [CrossRef]

27. Şahin DA, Kuşaslan R, Türel KS, Akbulut G, Arıkan Y, Dilek ON. Surgical Treatment in our hydatid cyst patients and efficiency of sphincterotomy with ERCP. The Medical Journal of Kocatepe 2006; 6: 11-6.

28. Dziri $C$, Haouet K, Fingerhut A, Zaouche A. Management of cystic echinococcosis complications and dissemination: where is the evidence? World J Surg 2009; 33: 1266-73. [CrossRef]

29. Wang Y, Zhang X, Bartholomot B, Liu B, Luo J, Li T, et al. Classification, follow-up and recurrence of hepatic cystic echinococcosis using ultrasound images. Trans R Soc Trop Med Hyg 2003; 97: 20311. [CrossRef]

30. Gottstein B, Reichen J. Echinococcosis/hydatidosis. Manson's Tropical Diseases. Ed: Cook GC. WB Saunders Company Ltd, Twentieth Edition. 1996.p.1486-508.

31. Altıntaş N, Yazar S. Immune Diagnosis in Cystic Echinococcosisde. Echinococcosis. Ed: Altıntaş N, Tınar R, Çoker A. Hydaditology Association Publications. İzmir-2004. pp: 159-80

32. Biava MF, Dao A, Fortier B. Laboratory Diagnosis of Cystic Hydatic Disease. World J Surg 2001; 25: 10-4. [CrossRef]

33. Akgün S. Specialization Thesis; "Determination of Antibodies Againsts Echinoccoccus Granulosus with IHA, IFA and ELISA and Evaluation of Antibody Variety". Gaziantep University Department of Microbiology and Clinical Microbiology. Thesis Advisor; Assoc. Prof. Tekin Karslıgil. Gaziantep - 2008.

34. Yılmaz A, Uslu H, Aktaş F. 2009-2013 Yıllari Arasında Erzurum Bölge Hastanesindeki Kistik Ekinokokkozis Şüpheli Hastaların Indirekt Hemaglütinasyon (IHA) Metoduyla Değerlendirilmesi. Gümüşhane University Journal of Health Sciences 2016; 5: 23-32. 